always be associated with Cockle Park, of which he has been director and where for a number of years he was, as a young man, personal assistant to Prof. Douglas Gilchrist. At present he is engaged on a history of Cockle Park in order to place in perspective the substantial contributions of Somerville, Middleton and Gilchrist to modern agricultural thought and practice. Recently he has published a book on the lifo of Robert Bakewell, of Dishley, in which is given a most interesting series of letters written by Bakewell, towards the end of the eighteenth century, to George Culley, a notable Northumbrian farmer, who was largely responsible for the development of the Border Leicester breed of sheep. Prof. Pawson is also well known in the Methodist Church, and during 1951-52 was vice-president of the Methodist Conference of Great Britain.

Prof. T. W. Walker

Prof. Walker, professor of soil science at Canterbury Agricultural College, New Zealand, follows Prof. Pawson. Prof. Walker graduated with first-class honours in chemistry from the University of London in 1936. He was awarded the D.I.C. and Ph.D. for his thesis on "The Influence of Soil Type on the Growth of Plants". Afterwards, he was awarded a Salters Fellowship and spent two years at Rothamsted working on physical and chemical problems of soils. His research was interrupted by the War and he became interested in more immediate problems in connexion with the food production programme. In this he was closely associated with Dr. E. M. Crowther. In 1946, on the inception of the National Agricultural Advisory Service, he was appointed provincial advisory chemist for the West Midland Province, and he held this post until 1951, when he was appointed to tho chair of soil chemistry in New Zealand. In his present post he has created an enviable reputation, not only for the quality of his research but also for the competent way he can interpret this work to farmers. His particular reseurch interests in recent years have been ecncerned with the response of crops to minor elements, in particular molybdenum and sulphur. Prof. Walker will take up his duties at King's College at tho beginning of the 1958-59 session. His chair is a newly established one, but in fact he replaces Prof. H. C. Pawson.

\section{End of the Rocket of the First Artificial Earth Satellite}

IT is reported from Moscow that observations of the carrier rocket of the first artificial Earth satellite show that about midnight on November 30 the orbital period of the rocket began to diminish rapidly and it lost height. In the early hours of December 1 , as the rocket passed over the areas of Irkutsk, the Chukotka Peninsula, Alaska and the western coast of North America, it re-entered the denser layers of the Earth's atmosphere and began to burn up. It is reported from the United States that the last instrumental observation of the carrier rocket was made about midnight on November 30 as it passed over western Pennsylvania. The life of the rocket carrier as an Earth satellite from its launching on October 4 was thus 58 days, in which time it had executed 879 revolutions of the Earth.

\section{Rocket Testing Ranges}

THe Minister of Defence, Mr. Duncan Sandys, announced, in reply to a question in the House of
Commons on December 4 regarding the Western Isles guided-missiles scheme, that after re-examining the scheme in the light of the changes in defence policy and as part of the campaign for economy in public expenditure, the Government had decided to provide in the Hebrides facilities for firing surfaceto-surface rockets only. Accordingly, less land would be required in the Hebrides and the construction programme there would be greatly curtailed. Arrangements were being made to explain the position to the islanders. The review, while confirming the need for this range for surface-to-surface rockets, had shown that most of the necessary Service firings with airto-air and surface-to-air missiles could be carried out at the Ministry of Supply rocket establishment at Aberporth and the remainder at the Army gunuery range at Ty Croes in Anglesey. Some additional instrumentation and other facilities would be required on these ranges, but the overall effect would be to reduce the capital cost of the whole scheme from about $£ 20$ million to about $£ 5$ million, with further substantial savings in running costs and in manpower. Of the $£ 500,000$ already spent on works, almost all would be required for the surface-tosurface rocket range.

\section{Creep Tests on Materials for Gas-cooled Reactors}

NEW research equipment designed to provide preliminary creep and stress-rupture data on metals and alloys in gaseous atmospheres at high temperatures and pressures has recently been installed in the materials research laboratory of the General Electric Company's Atomic Energy Division at Erith. Kent. Twolve creep-test units have already done valuable basic work in investigating the properties of magnesium alloys, widely employed for fuel. element cans, in carbon dioxide atmospheres. They can be readily converted for future work to deal with other materials in other gases. This equipment has been installed to meet the requirement for applied research facilitios beyond the range of normal metal. lurgical laboratory equipment. This requirement arises from the urgency of the British nuclear power programme, which demands that investigations be carried out at a much greater pace than is usually imposed on metallurgical development work.

\section{Photographic Observations at the Union Obser- vatory, South Africa}

UNION Observatory Circular No. 116 (1957) contains seven papers, the first of which, "Photographic Observations of Minor Planets", by J. A. Bruwer, gives the positions of 163 minor planets (mean place 1950.0), followed by "Photographic Observation of Comets", by the same author. The latter paper gives the mean places of Comet Johnson (1949 ii) for five dates in August and September 1956, and of Comet Crommelin for November 7, 1956. W. S. Finsen's paper, "Photographic Observations of Mars", contains the results of some 54,000 experimental exposures during the favourable oppositions of Mars in 1939,1954 , and 1956. A selection of black and white enlargements of these exposures on $16-\mathrm{mm}$. colour film is reproduced in two plates, and colour enlargements-both paper prints and transparencies-have also been made. 'The best results were obtained with the $26 \frac{1}{2}$-in. telescope stopped down to $13 \frac{1}{2}$ in., using a Goerz telenegative lens and Kodachrome film. The camera was a Paillard 'Bolex' equipped with a beamsplitter or prismatic eyepiece for the visual monitoring 